\title{
Isolation and Characterization of Thermostable Protease Producing Bacteria from Soap Industry Effluent.
}

\author{
Shivangi Thakur ${ }^{1}$, Dr. Ela Tiwari ${ }^{2}$ \\ Research Scholar \& Prof.Dept. of Botany \\ 1,2 (Dept. of Botany Govt.Girls.Auto.P.G.College,Saugor ,M.P.)
}

\begin{abstract}
This study is a search for potential thermostable protease producing strain. Among nine protease producing strains screened from soap industry effluent, one was selected as promising thermostable protease producer and identified as Bacillus subtilis. The activity of the protease produced by this organism is stable up to $70^{\circ} \mathrm{C}$. The optimum yield was achieved after 48 hours of culture, at $65^{\circ} \mathrm{C}$ with the $\mathrm{pH}$ 8.0. The maximum protease activity was observed at $65^{\circ} \mathrm{C}$ and at $\mathrm{pH}$ 8.0.

Key Words: Thermostable protease; Bacillus subtilis; Soap industry effluent.
\end{abstract}

\section{Introduction}

The industrial enzyme represents a major part of the global enzyme business and it has grown about Dollar 1.4 US billion annually. The scope of Industrial enzymes is growing because they (i) offer less polluting processes than chemical catalyst (ii) perform reactions with higher specificity than chemical catalyst and (iii) perform reaction for which chemical catalyst are not known (Claivielle et al. 1996). Among these enzymes, protease is the most important enzyme and accounts for about $60 \%$ of the total worldwide sale (Gupta et al. 2002). With respect of properties of this enzyme and its capacity for degradation of different protein source, these proteases having a long history of application in different industries viz. detergents, food-brewing (Jany et al. 1986, Lerch et al. 1993), meat tenderization, baking, manufacture of soya products, diary, leather (Eaton et al. 1995, Goel et al 1998). Mostly, all industrial processes are carried out at higher temperature where normal enzymes become unstable (Amann et al. 1995, Egelseer et al. 1995. Therefore, there is an ample scope for searching thermostable proteases which can resist the changes in environmental conditions in which they are supposed to work in industries. A number of bacteria have been newly isolated from the hot springs over past few years (Haki et al. 2003, Azeredo et al. 1998). However, information on extra-cellular proteolytic enzyme producing bacteria from non-thermal source has been scarce so far. In pursuit for the search of potential thermostable protease producing bacteria from soap industry effluent because of its content of natural proteins (Beveridge et al. 1999, Frolund et al. 1995, Martinez et al. 1996). The extra cellular thermostable protease and its features suggest its application in detergent industry which generally use protease synthesized by chemical methods.

\section{Materials And Methods}

Collections of samples: The protein rich samples were collected from soap industries of Saugor, Madhya Pradesh, India. Effluent samples were stored in a cold chamber at $4^{\circ} \mathrm{C}$ for future use.

Isolation of thermostable protein producing bacteria : Enumeration of total heterotrophic population from sample was performed by dilution agar plating technique. The grown colonies are checked for their protease producing capability by inoculating them in autoclaved skimmed milk medium and incubated at $37^{\circ} \mathrm{C}$ for $24-48$ $h$. Depending on the diameter of the clear zone around the colonies, nine protease producing bacteria were selected and were maintained by streaking them onto agar slant and storing them at $4^{\circ} \mathrm{C}$ in the refrigerator. Further, they were checked for the thermal stability. All the nine cultures was inoculated in nine different Erlenmeyer flasks containing $50 \mathrm{~mL}$ Nutrient broth each and incubated at $50^{\circ} \mathrm{C}$ for 36 hours in water bath shaker. After the incubation period $1 \mathrm{ml}$ of broth was plated in casein-agar plate and the remaining broth was incubated at $60^{\circ} \mathrm{C}$. This method was followed up to $80^{\circ} \mathrm{C}$. Plates were observed for getting the thermostable protease producing bacteria (Nybroe et al.1992).

Identification of the isolated bacteria: Gram staining, spore staining, negative staining and biochemical tests were done to identify the isolated bacteria. The following tests which were done for this purpose are Methyl red test, Triple Sugar Iron test, Indole test, Catalase test, Nitrate reduction test, Hydrolysis of starch and citrate utilization test.

Determination of the protease activity: Protease activity was determined and the method was adopted from Bhosale et al. (1995) using casein as the substrate. Enzyme solution was added to $3.0 \mathrm{ml}$ of substrate solution 
and the mixture was incubated at $65^{\circ} \mathrm{C}$ for $20 \mathrm{~min}$. The reaction was stopped by addition of $3.2 \mathrm{ml}$ of TCA mixture and kept at $65^{\circ} \mathrm{C}$ for 30 minute followed by filtration. The absorbance of the filtrate was measured by spectrophotometer at $280 \mathrm{~nm}$. One unit of protease activity is defined as the amount of enzyme required to produce $1 \mu \mathrm{g}$ (micro gram) of tyrosine per hour under the condition described (Nybroe et al. 1992). Each data point is the average of at least three determinations.

Optimization of enzyme activity : The effect of $\mathrm{pH}$ and temperature on the rate of reaction was studied by assaying elute in the range of $\mathrm{pH} 5.0$ to 10.0 and in the following temperature from $50^{\circ} \mathrm{C}$ to $75^{\circ} \mathrm{C}$ (figure 1 and figure 2).

\section{Results And Discussion}

A new thermostable protease producing bacteria was isolated from soap industry effluent and the stability was checked (Table 1). It showed excellent growth at $65^{\circ} \mathrm{C}$ on nutrient medium. The widest zone diameter $(1.3 \mathrm{~cm})$ was obtained for this organism among the others screened and showed protease activity of $133.8 \mathrm{IU} / \mathrm{ml} / \mathrm{hr}$. (IU= International units, $\mathrm{ml}=$ mili litre, $\mathrm{hr}=$ hour)

Table 1. Stability of the thermostable protease produced by the selected bacteria

\begin{tabular}{|c|c|c|}
\hline Temperature $\left({ }^{\circ} \mathrm{C}\right)$ & O.D at $280 \mathrm{~nm}$ & Protease activity(IU/ml/hr) \\
\hline 50 & 0.987 & 86.4 \\
\hline 55 & 1.134 & 98.4 \\
\hline 60 & 1.378 & 118.4 \\
\hline 65 & 1.533 & 133.8 \\
\hline 70 & 1.339 & 107.6 \\
\hline 75 & 0.228 & 21.6 \\
\hline
\end{tabular}

The protease produced by this organism was found to withstand up to $70^{\circ} \mathrm{C}$. This organism was selected as the thermostable protease producing bacteria. The growth profile showed that its lag phase lasted for $20 \mathrm{hrs}$. After the lag phase protease started and the maximum protease production was observed in its late log phase, i.e., after $48 \mathrm{~h}$. Preliminary experiments showed that the strain was Rod shaped, spore forming, gram positive bacteria. It showed positive reaction for catalase, MR, VP, hydrolysis of starch, decomposition of citrate and negative reactions for urease, indole, growth on Mc.Conkey agar and nitrate reduction. The morphology and the biochemical data on the growth of the bacteria indicated that the bacteria belong to Bacillus species. However, molecular study and ribotyping method will reveal the true identity of the bacteria. Though the protease showed activity at wide range of $\mathrm{pH} 5.0$ to 10.0, the optimum activity was found to be at $\mathrm{pH}$ of 8.0. The optimum temperature for purified protein activity was $65^{\circ} \mathrm{C}$ while it can withstand the temperature up to $70^{\circ} \mathrm{C}$ (Fig 1 and 2).It thus became imperative to find new methods in order to decrease and/or re-use these wastes. The use of proteases would also make it possible to reduce the use of harmful chemicals and wastes in the environment because these chemicals can be replaced by these newly produced proteases. Thus, the present work demonstrates the effectiveness of the production of thermostable proteases by thermophilic bacteria using municipal waste water sludge as a culture medium. This would also reduce the quantity of sludge for final disposal. The quantity of biosolids produced by community wastewater treatment plants can now be reduced by reuse of them. Eventually, all biosolids can be recycled into new eco-friendly products like biopesticides, bioplastics, biocatalysers or in any kind of biogas. It proves that high protease activity can be efficiently extracted from activated sludge. Given the central role extracellular enzymes play in the process of organic matter removal in wastewater treatment processes, and the mildness of the extraction procedure, the enzyme thus extracted can serve as a good starting material for further detailed biochemical and molecular characterization.

\section{Conclusion}

It was concluded that the isolated Bacillus strain having potential to produce thermostable protease. In general, thermostable protease producing bacteria was found in hot springs or any other thermal source. However, the present study shows the existence of Bacillus strain which can produce industrially important thermostable enzyme by existing in the non-thermal source such as soap effluent. The isolated strain can grow in nutrient medium. The highest protease activity was achieved at $\mathrm{pH} 8.0$ and temperature at $65^{\circ} \mathrm{C}$. Further investigations are needed on genetic analysis of this Bacillus strain and structure elucidation of the purified protein for industrial exploitation. 


\section{References}

[1] Amann RI, Ludwig W, Schleifer KH. Microbiol Rev 1995; 59: 143-169.

[2] Azeredo J, Oliveira R, Lazarova V. A new method for the extraction of exopolymers from activated sludges. Water Sci Tech 1998; 37:367-370.

[3] Beveridge TJ. Structures of Gram-negative cell walls and their derived membrane vesicles. J Bacteriol 1999;181: 4725-4733.

[4] Bhosale. S.H., M.B. Rao., V.V. Deshpande and M.C. Srinivasan. (1995). Enzyme Microb. Technol. 17, 136-139.

[5] Claivielle, Doug S. Burdette and Gregory Zeikus, Thermozyme, Eds, EL-Grewely M.R. (1996). Biotechnology Annual Reviws.

[6] Dueholm TE, Andreasen KH, Nielsen PH. Conceptual model for the transformation of long chain fatty acids and triglyceride in activated sludge. Water Sci Technol 2000; 43: 165-172.

[7] Eaton AD, Clesceri LS, Greenberg AE, 1995. APHA, Standard Methods. Standard Methods for the examination of water and wastewater. American Public Health Association, American Water Works Association and Water Environment Federation.

[8] Egelseer E, Schocher I, Sara M, Sleytr UB. The S-layer from Bacillus stearothermophilus DSM 2358 functions as an adhesion site for a high-molecular-weight amylase. J Bacteriol 1995;177:1444-1451.

[9] Frolund B, Palmgren R, Keiding K, Nielsen PH. Enzymatic activity in the activated sludge floc matrix. Appl Microbiol Biotechnol 1995;43:708-716.

[10] Goel R, Mino T, Satoh H, Matsuo T. Water Res 1998; 32: 2081-2088.

[11] Gupta R., Beg Q.K and Lorenz P. (2002). Appl. Microbial. Biotechnol. 59, 15-32.

[12] Haki G.D, S.K Rakshit . Developments in industrially important thermostable enzymes, a review. Bioresourse Technology. 2003; 89: 17-34.

[13] Jany, K.D., Lederer, G. and Mayer, B. (1986). FEBS Lett., 199, 139-144.

[14] Kloeke FV, Geesey GG. Localization and identification of populations of phosphatase-active bacterial cells associated with activated sludge flocs. Microbiol Ecol 1999; 38: 201-214.

[15] Lerch RN, Barbarick KA, Azari P, Sommers LE, Westfall DG, J Environ Qaul 1993;22:620-624.

[16] Martinez J, Smith DC, Steward GF, Azam F. Variability in ectohydrolytic enzyme activities of pelagic marine bacteria and its significance for substrate processing I the sea. Aquat Microb Ecol 1996; 10: 223-230.

[17] Nielsen PH, Roslev P, Dueholm T, Nielsen JL. Microthrix parvicella, a specialized lipid consumer in anaerobic-aerobic activated sludge plants. Water Sci Tech 2002; 46: 73-80.

[18] Nybroe O, Jorgensen PE, Henze M. Enzyme activities in waste water and activated sludge. Water Res 1992;26: 579-584.

[19] Raunkjaer K, Hvitved-Jacobsen T, Nielsen PH. Measurement of pools of protein, carbohydrate and lipid in domestic wastewater. Water Res 1994; 8: 251-262.

Figure 1

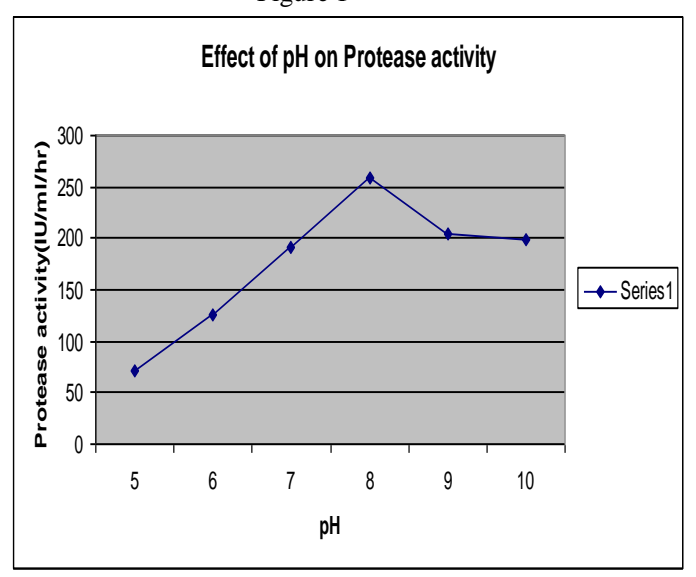

(IU= International units, $\mathrm{ml}=$ mili litre, hr=hour, $\mathrm{pH}=$ hydrogen ion concentration)
Figure 2

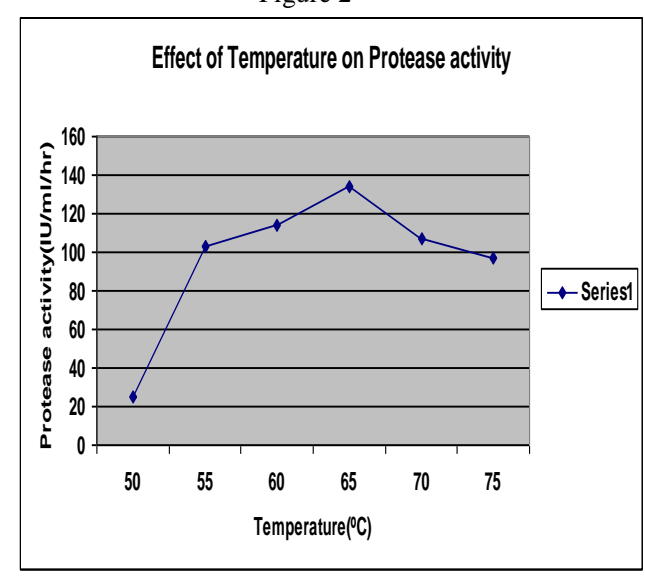

(IU= International units, $\mathrm{ml}=$ mili litre, hr=hour, ${ }^{\circ} \mathrm{C}=$ degree celsius) 